\title{
Anti Helminthis Activity of Alangium salviifolium against Pheretima posthumous
}

\author{
K.P. Kochuthressia* \\ Department of Botany, Carmel College, Mala (P.O), Thrissur-680732, Kerala, India \\ *Corresponding author
}

\section{A B S T R A C T}

\section{Keywords}

Alangium salviifolium, Anti helminthis activity, Pheretima posthumous

Article Info

Accepted:

22 October 2018

Available Online:

10 November 2018
The present study was intended to delineate the Anti Helminthis activity of Ankolam leaf extract. The crude extract was obtained by the employment of Soxhlet extraction method. The extract was used to screen the antagonistic activity in vitro by taking Pheretima posthumous as the study subject. B y the employment of molecular sequencing the identity of plant was confirmed as Alangium salviifolium. The results obtained proved the capability of extract to down regulate the biological activities of subject. Mortality was induced by varying concentrations $(100-1000 \mathrm{ppm} / \mathrm{ml})$. Interestingly the antagonistic activity was in direct proportional with the extract administrated. The analysis of phytoconstituents revealed that the extract is composed of polyphenols, Saponins, Flavonoids etc. Therefore, it is assumed that the biological activities are complimented by the phytocomponents. The results obtained from the current studies can be further exploited in the field pharmaceuticals.

\section{Introduction}

Despite of some biological advantages in the field of agriculture Helminthis are known for its expanded infection and disease spreading abilities. Therefore, it is crucial to improve efficient control agents against them (Cabardo and Portugaliza, 2017).

Trematodes, the causal agents of schistosomiasis an important parasites of economic and public health implications. Schistosomiasis affects over 240 million people worldwide, with up to 700 million individuals living at risk of infection (Cala et al., 2012). The disease caused up to 250,000 deaths per year in the last decade
(Kumarasingha et al., 2016). Similarly, Helminthis infection causes huge revenue in agro farming. There have been several synthetic chemical compounds and nanoparticles proven their anti helminthis activity. However, it is also observed that these compounds are mostly toxic to the environment. In this juncture it is essential to develop suitable ethnobotanical agents against this threat (Khan et al., 2018).

Alangium salvifolium Wang. belongs to the family Alangiaceae and is commonly known as sage leaved Alangium. It is a well-known traditionally used medicinal plant in India and it is also one of the most versatile medicinal plant having a wide spectrum of biological 
activities like antidiabetic, antiulcer, analgesic, anti-inflammatory, antimicrobial, antioxidant, anti-arthritic, diuretic, antifertility, anthelmintic, antiepileptic and antifungal (Shravya et al., 2017). A. salvifolium is a tall thorny tree and the genus contains 17 species of small trees, shrubs and lianas. Alangium name has been derived from the Malayalam word Alangi. Almost all the parts (root, bark, leaves, seeds and fruits) are known to have important therapeutic uses and are extensively used for different purposes in the indigenous herbal medicines (Saraswathy et al., 2010).

A. salvifolium is widely distributed in South East Asia, from India to China, Thailand, Philippines, Indonesia and Papua New Guinea. It is also found in Africa, Madagascar, Southern and Eastern Asia, tropical Australia, the western Pacific Ocean islands and New Caledonia. In India, it is found throughout the Hyderabad forests and Sitamata wildlife sanctuary, Rajasthan (Singh Tanwer and Vijayvergia, 2014)

\section{Materials and Methods}

\section{Plant collection, identification and extract preparation}

The leaf of Ankolam were collected from Botanical garden of St. Mary's College, Thrissur and the identity of plant was confirmed by molecular sequencing (Zhang et $a l ., 2016)$. The dried leaves were ground to a course powder and $50 \mathrm{~g}$ of the powdered plant materials is subjected to extraction by using Soxhlet apparatus using 95\% ethanol as the solvent.

The filtrate is collected after 72 hours. It is twice filtered using Whatman no. 1 filter paper and extracts were concentrated by evaporation at room temperature. The dried residue is kept in refrigerator for further studies (Vadakkan et al., 2018).

\section{Collection of study subjects}

Pheretima posthumous were collected from vermicomposting unit of St. Mary's College, Thrissur, Kerala and washed with normal saline to remove all fecal matter which was brought to Laboratory. The identity of collected organisms was confirmed by the help of Dr. Dalie Domnic, Head of the department, Department of Zoology, St. Mary's College, Thrissur, Kerala. Study subjects were acclimatized in aquaria for a minimum period of four days in holding tanks containing aerated, de-chlorinated tap water and washed sand.

\section{Screening of anthelmintic activity}

Test samples of plant extract was prepared at the concentrations $100-1000 \mathrm{ppm} / \mathrm{ml}$ in 10 $\mathrm{ml}$ of distilled water and five worms of approximately equal size (same type), about 3 $\mathrm{g}$ weight were placed in each petridish containing $10 \mathrm{ml}$ of above test solution of extracts. All the test solutions were prepared freshly before starting the experiments. Observations were made for the time taken for paralysis was noted when no movement of any sort could be observed except when the worms were shaken vigorously. Time for death of treating worms were recorded after ascertaining that worms neither moved when shaken vigorously nor when dipped in warm water. Standard drug Albendazole is taken as control for comparison (Jacob, 2018).

\section{Phytochemical analysis of plant extract}

Phytochemical screening was carried out to assess the qualitative chemical composition of crude ethanolic extracts of Alangium salviifolium. Standard screening tests using conventional protocol, procedure, and reagents were conducted using standard procedures to identify the constituents as described previously (Belemlilga et al., 2016). 


\section{Results and Discussion}

\section{Identification of source plant}

By the employment of $r b c L$ gene sequencing and phylogenetic tree construction it was evident that the source plant is Alangium salviifolium (Figure 1).

The BLAST results suggested that source plant is showing maximum similarity that with Alangium salviifolium ribulose-1,5bisphosphate carboxylase/oxygenase large subunit (rbcL) gene, partial cds; chloroplast which is submitted under the accession number JF308648.1 and Alangium kurziiribulose 1,5-bisphosphate carboxylase large subunit (rbcL) gene, partial cds; chloroplast gene which is submitted under the accession number AF384108.1. Molecular characterization is used as a successful tool for the identification of plants (Vadlapudi and Kaladhar, 2012).

Effect of plant extract in causing death and paralysis in Pheretima posthumous

Ethanolic extract of Alangium salviifolium possess dose dependent anthelmintic action. At higher concentrations, it produces paralytic effect much earlier and the time to death at higher doses, the plant extract induces 100\% mortality (Figure 2). It was observed that time required for inducing paralysis and causing death is in directly proportional that with the concentration of extract administrated.

Time taken for inducing paralysis was only 19 minutes when the concentration was 1000 $\mathrm{ppm} / \mathrm{ml}$ whereas the time of survival was prolonged to 67 minutes in lower concentration of antagonist.

Fig.1 Phylogenetic tree of Alangium salviifolium source plant

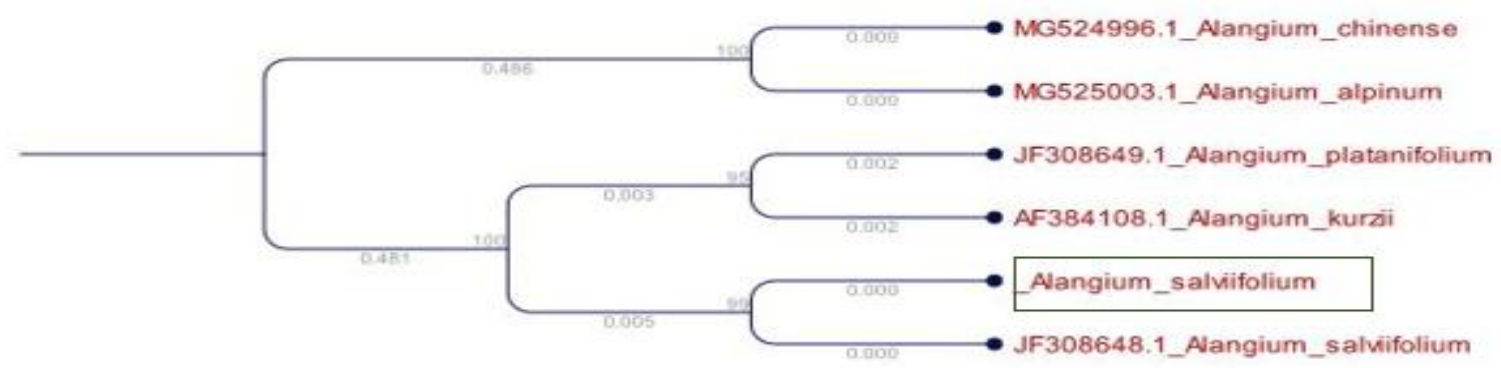

Fig.2 Antihelmintic activity of extract in varying concentration

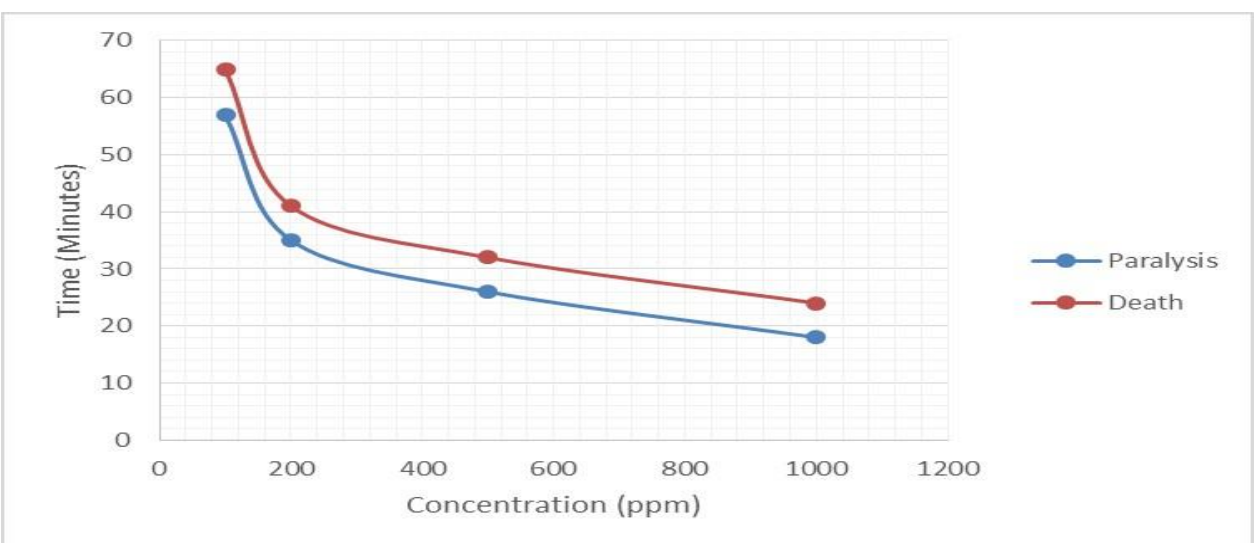


A similar kind of activity was reported in aqueous leaf extract of Annonamuricata L. (Annonaceae) against Haemonchus contortus from sheep (Ferreira et al., 2013). Similarly plant extracts from Brazilian savanna also possessed Anthelmintic activity(Oliveira et al., 2017). Generally, Albendazole eliminate worm chiefly by inducing flaccid paralysis interestingly plant extract also showed same clinical symptoms therefore we assume that the mechanism of plant extract is similar to that of Albendazole (Haque et al., 1993).

\section{Phytochemical analysis of plant extract}

Phytochemical screening of ethanolic extract of Alangium salviifolium showed the presence of alkaloids, coumarins, terpenoids, cardioglycosides, flavonoids, saponins, quinine and phenols as major chemical constituents. Among these, poly phenols, flavonoids are said to have anthelmintic activity (Nayak et al., 2012). Therefore, it is assumed that the activity is contributed by the presence of the polyphenols and flavonoids. From the results, it is evident that ethanolic extract of Alangium salviifoliumpossess anthelmintic properties in a dose dependent way. Alangium salviifolium extract kills the worm even in low concentrations within short duration of time compared to standard drug Albendazole. It justifies the claims of its potential anthelmintic property.

\section{Acknowledgement}

I would like to acknowledge Marian Centre for Advanced Research (MCAR), research division of St. Mary's College, Thrissur, Kerala, India for providing research support and infrastructure.

\section{References}

Belemlilga, M.B., Traoré, A., Ouédraogo, S., Kaboré, A., Tamboura, H.H., Guissou,
I.P., 2016. Anthelmintic activity of Saba senegalensis (A.DC.) Pichon (Apocynaceae) extract against adult worms and eggs of Haemonchus contortus. Asian Pac. J. Trop. Biomed. 6, 945-949. https://doi.org/10.1016/ j.apjtb.2016.07.015

Cabardo, D.E., Portugaliza, H.P., 2017. Anthelmintic activity of Moringa oleifera seed aqueous and ethanolic extracts against Haemonchus contortus eggs and third stage larvae. Int. J. Vet. Sci. Med. 5, 30-34. https://doi.org/ 10.1016/j.ijvsm.2017.02.001

Cala, A.C., Chagas, A.C.S., Oliveira, M.C.S., Matos, A.P., Borges, L.M.F., Sousa, L.A.D., Souza, F.A., Oliveira, G.P., 2012. In vitro Anthelmintic effect of Melia azedarach L. and Trichilia claussenii C. against sheep gastrointestinal nematodes. Exp. Parasitol. 130, 98-102. https://doi.org/ 10.1016/j.exppara.2011.12.011

Ferreira, L.E., Castro, P.M.N., Chagas, A.C.S., França, S.C., Beleboni, R.O., 2013. In vitro anthelmintic activity of aqueous leaf extract of Annona muricata L. (Annonaceae) against Haemonchus contortus from sheep. Exp. Parasitol. 134, 327-332. https://doi.org/10.1016/j.exppara.2013.0 3.032

Haque, M.A., Hollister, W.S., Willcox, A., Canning, E.U., 1993. The Antimicrosporidial Activity of Albendazole. J. Invertebr. Pathol. 62, 171-177. https://doi.org/https://doi. org/10.1006/jipa.1993.1092

Jacob, F., 2018. Anti Helminthis and Molluscicidal Activity of Momordica dioica against Pheretima posthumous and Indoplanorbis exustus. Int. J. Curr. Microbiol. Appl. Sci. 7, 3969-3974.

Khan, A., Tak, H., Nazir, R., Lone, B.A., 2018. In vitro and in vivo anthelmintic activities of Iris kashmiriana Linn. J. 
Saudi Soc. Agric. Sci. 17, 235-240. https://doi.org/10.1016/j.jssas.2016.05.0 01

Kumarasingha, R., Preston, S., Yeo, T.C., Lim, D.S.L., Tu, C.L., Palombo, E.A., Shaw, J.M., Gasser, R.B., Boag, P.R., 2016. Anthelmintic activity of selected ethno-medicinal plant extracts on parasitic stages of Haemonchus contortus. Parasites and Vectors 9, 1-7. https://doi.org/10.1186/s13071-0161458-9

Nayak, S., Chakraborti, C.K., Jaiswal, P., Sah, U.K., Mohanta, D.S. Das, 2012. Correlation between the phytochemical constituents and anthelmintic activity of Lawsonia inermis leaf extracts. Int. J. Res. Ayurveda Pharm. 3, 559-562.

Oliveira, A.F., Costa Junior, L.M., Lima, A.S., Silva, C.R., Ribeiro, M.N.S., Mesquista, J.W.C., Rocha, C.Q., Tangerina, M.M.P., Vilegas, W., 2017. Anthelmintic activity of plant extracts from Brazilian savanna. Vet. Parasitol. 236, 121-127. https://doi.org/https:// doi.org/10.1016/j.vetpar.2017.02.005

Saraswathy, A., Meena, A.K., Shakila, R., Sunil Kumar, K.N., Ariyanathan, S., 2010. Pharmacognostic studies on Alangium salvifolium (Linn.f.) Wang. root bark. Pharmacogn. J. 2, 374-380. https://doi.org/https://doi.org/10.1016/S 0975-3575(10)80018-5

Shravya, S., Vinod, B.N., Sunil, C., 2017.
Pharmacological and phytochemical studies of Alangium salvifolium Wang. - A review. Bull. Fac. Pharmacy, Cairo Univ. 55, 217-222. https://doi.org/ 10.1016/j.bfopcu.2017.07.001

Singh Tanwer, B., Vijayvergia, R., 2014. Biological evaluation of Alangium salviifolium (L. F.) Wangerin. J. Chem. Pharm. Res. 6, 611-618.

Vadakkan, K., Gunasekaran, R., Choudhury, A.A., Ravi, A., Arumugham, S., Hemapriya, J., Vijayanand, S., 2018. Response Surface Modelling through Box-Behnken approach to optimize bacterial quorum sensing inhibitory action of Tribulus terrestris root extract. Rhizosphere 6, 134-140. https://doi.org/ 10.1016/j.rhisph.2018.06.005

Vadlapudi, V., Kaladhar, D.S.V.G.K., 2012. Phytochemical evaluation and molecular characterization of some important medicinal plants. Asian Pacific J. Trop. Dis. 2, S26-S32. https://doi.org/https://doi.org/10.1016/S 2222-1808(12)60118-2

Zhang, D., Mo, X., Xiang, J., Zhou, N., 2016. Zhang et al., Afr J Tradit Complement Altern Med. (2016) 13 (6): 74-82 Molecular identification of original plants of Fritillariae cirrhosae bulbus, Zhang et al., Afr J Tradit Complement Altern Med. (2016) 13 (6): 74-82 13, $74-82$.

\section{How to cite this article:}

Kochuthressia, K.P. 2018. Anti Helminthis Activity of Alangium salviifolium against Pheretima posthumous. Int.J.Curr.Microbiol.App.Sci. 7(11): 2720-2724. doi: https://doi.org/10.20546/ijcmas.2018.711.311 